This is an electronic reprint of the original article. This reprint may differ from the original in pagination and typographic detail.

\author{
Author(s): Deyou, Tsegaye; Marco, Makungu; Heydenreich, Matthias; Pan, Fangfang; Gruhonjic, \\ Amra; Fitzpatrick, Paul A.; Koch, Andreas; Derese, Solomon; Pelletier, Jerry; Rissanen, \\ Kari; Yenesew, Abiy; Erdélyi, Máté
}

Title: Isoflavones and Rotenoids from the Leaves of Millettia oblata ssp. teitensis

Year: $\quad 2017$

Version:

Please cite the original version:

Deyou, T., Marco, M., Heydenreich, M., Pan, F., Gruhonjic, A., Fitzpatrick, P. A., Koch, A., Derese, S., Pelletier, J., Rissanen, K., Yenesew, A., \& Erdélyi, M. (2017). Isoflavones and Rotenoids from the Leaves of Millettia oblata ssp. teitensis. Journal of Natural Products, 80(7), 2060-2066. https://doi.org/10.1021/acs.jnatprod.7b00255

All material supplied via JYX is protected by copyright and other intellectual property rights, and duplication or sale of all or part of any of the repository collections is not permitted, except that material may be duplicated by you for your research use or educational purposes in electronic or print form. You must obtain permission for any other use. Electronic or print copies may not be offered, whether for sale or otherwise to anyone who is not an authorised user. 


\section{Isoflavones and Rotenoids from the Leaves of Millettia oblata ssp. teitensis}

Tsegaye Deyou, ${ }^{\dagger \dagger}$ Makungu Marco, ${ }^{\dagger}$ Matthias Heydenreich, ${ }^{\S}$ Fangfang Pan, ${ }^{\perp, \|}$ Amra Gruhonjic, ${ }^{\ddagger}, \nabla$ Paul A. Fitzpatrick, ${ }^{\nabla}$ Andreas Koch, ${ }^{\S}$ Solomon Derese, ${ }^{\dagger}$ Jerry Pelletier, ${ }^{\bigcirc}$ Kari Rissanen, ${ }^{\perp_{\odot}}$ Abiy Yenesew, ${ }^{*}{ }^{\dagger}$ and Máté Erdélyi ${ }^{*},+\#$

${ }^{\dagger}$ Department of Chemistry, University of Nairobi, P.O. Box 30197-00100, Nairobi, Kenya

${ }^{\ddagger}$ Department of Chemistry and Molecular Biology, University of Gothenburg, SE-412 96 Gothenburg, Sweden

${ }^{\S}$ Institut für Chemie, Universität Potsdam, Karl-Liebknecht-Straße 24-25, D-14476, Potsdam, Germany

${ }^{\perp}$ Department of Chemistry, Nanoscience Center, University of Jyvaskyla, P.O. Box 35, FI-40014, Jyvaskyla, Finland

"College of Chemistry, Central China Normal University, Wuhan, 430079, People's Republic of China

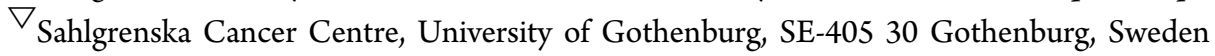

ODepartment of Biochemistry, McGill University, Montreal, QC H3G 1Y6, Canada

${ }^{\#}$ Swedish NMR Center, University of Gothenburg, P.O. Box 465, SE-405 30, Gothenburg, Sweden

\section{Supporting Information}

ABSTRACT: A new isoflavone, 8-prenylmilldrone (1), and four new rotenoids, oblarotenoids $\mathrm{A}-\mathrm{D}(\mathbf{2}-\mathbf{5})$, along with nine known compounds (6-14), were isolated from the $\mathrm{CH}_{2} \mathrm{Cl}_{2} / \mathrm{CH}_{3} \mathrm{OH}$ (1:1) extract of the leaves of Millettia oblata ssp. teitensis by chromatographic separation. The purified compounds were identified by NMR spectroscopic and mass spectrometric analyses, whereas the absolute configurations of the rotenoids were established on the basis of chiroptical data and in some cases by single-crystal X-ray crystallography. Maximaisoflavone J (11) and oblarotenoid C (4) showed weak activity against the human breast cancer cell line MDA-MB-231 with $\mathrm{IC}_{50}$ values of 33.3 and 93.8 $\mu \mathrm{M}$, respectively.
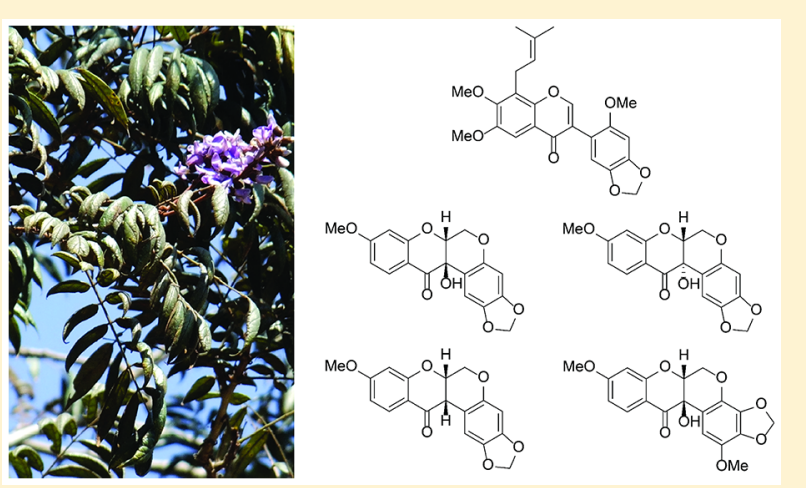

$\mathrm{T}$ he genus Millettia (family Leguminosae, subfamily Papilionoideae) contains over 200 species that are distributed in the tropical and subtropical regions of Africa, Asia, and Australia. ${ }^{1,2}$ The majority of these plants, which are typically trees, shrubs, or liana, are known for traditional medicinal applications. ${ }^{1}$ Millettia nitida var. hirsutissima and M. speciosa are, for example, used in Chinese folk medicine to alleviate dysmenorrhea and rheumatic pain and to treat paralysis. ${ }^{3,4}$ In Cameroon, the concoction of the roots and stem bark of M. griffoniana is employed orally for the treatment of boils, insect bites, inflammation, amenorrhea, sterility, and menopausal syndromes. ${ }^{5,6}$ The roots of $M$. usaramensis are used as an antidote against snake bite, ${ }^{7}$ while $M$. oblata is used to treat stomachache and as a remedy for cough, swollen body, and bladder problems in Kenya and Tanzania. ${ }^{1}$

The genus Millettia is rich in flavonoids including chalcones, isoflavones, and rotenoids, some of which show valuable antiplasmodial and cytotoxic activities. ${ }^{7,8}$ In a previous study, we reported isoflavones, rotenoids, and a triterpene from the stem bark of M. oblata ssp. teitensis. ${ }^{8}$ Herein, the isolation and characterization of a new isoflavone and four new rotenoids, along with nine known compounds, are reported from the leaves of the same plant. Selected compounds were evaluated for cytotoxicity against the MDA-MB-231 human breast cancer cell line and for translation inhibitory activity.

\section{RESULTS AND DISCUSSION}

The air-dried and ground leaves of $M$. oblata ssp. teitensis were extracted with $\mathrm{CH}_{2} \mathrm{Cl}_{2} / \mathrm{CH}_{3} \mathrm{OH}(1: 1)$ to afford a dark green crude extract. Chromatographic separation of this extract gave a new isoflavone (1), four new rotenoids (2-5), the known rotenoids 12a-hydroxymunduserone (6), ${ }^{9}$ munduserone (7), ${ }^{9}$ 6a,12a-dehydrodeguelin (8),,$^{10,11}$ and tephrosin (9), ${ }^{9-11}$ and the known isoflavones maximaisoflavone $\mathrm{B}(\mathbf{1 0}),{ }^{8,12}$ maximaisoflavone J (11), ${ }^{8}$ maximaisoflavone G (12), ${ }^{13}$ milldurone (13), ${ }^{14-16}$ and $7,2^{\prime}, 5^{\prime}$-trimethoxy-3',4'-methylenedioxyisoflavone (14). ${ }^{17}$ Among the known compounds, the rotenoids 6a,12a-dehydrodeguelin (8) and tephrosin (9) demonstrated cytotoxic activities against HepG2, C26, LL2, and B16 cancer cell lines, with $\mathrm{IC}_{50}$ values of $0.56-15.95$ and $1.35-9.85 \mu \mathrm{M}$,

Received: March 28, 2017

Published: June 30, 2017 


\section{Chart 1}<smiles>COc1ccc2c(c1)O[C@H]1COc3cc4c(cc3[C@@]1(O)C2=O)OCO4</smiles><smiles>COc1ccc2c(c1)O[C@H]1COc3cc4c(cc3[C@@H]1C2=O)OCO4</smiles><smiles>COc1ccc2c(c1)OC[C@@]1(C2=O)C(=O)[C@@]2(O)c3cc(OC)c4c(c3OC[C@@H]2Oc2cc(OC)ccc21)OCO4</smiles><smiles></smiles><smiles>COc1cc2c(cc1-c1coc3cc(O)ccc3c1=O)OCO2</smiles><smiles>COc1cc2occ(-c3cc4c(cc3OC)OCO4)c(=O)c2cc1OC</smiles><smiles>COc1ccc2c(=O)c(-c3cc(OC)c4c(c3OC)OCO4)coc2c1</smiles>

respectively. ${ }^{18}$ Strong inhibitory effects on NO production and significant insecticidal activity were also reported for $\mathbf{8}$ and $\mathbf{9}$, with the latter being a common property of rotenoids. ${ }^{19,20}$ Moreover, the Neorautanenia mitis extract containing 12ahydroxyrotenoids showed strong acaricidal and insecticidal activities. $^{21}$

Compound 1 was obtained as a colorless, amorphous solid, whose molecular formula was deduced as $\mathrm{C}_{24} \mathrm{H}_{24} \mathrm{O}_{7}$ based on HRESIMS $\left([\mathrm{M}+\mathrm{H}]^{+} m / z\right.$ 425.1609, calcd 425.1601) and NMR analyses (Table 1). A singlet at $\delta_{\mathrm{H}} 7.97(\mathrm{H}-2)$, in the ${ }^{1} \mathrm{H}$ NMR spectrum, and the ${ }^{13} \mathrm{C}$ NMR signals at $\delta_{\mathrm{C}} 154.2$ (C-2), 121.4 (C-3), and 175.9 (C-4) were consistent with an isoflavone core structure that was corroborated by its UV spectrum $\left(\lambda_{\max }\right.$ at 280 and $\left.305 \mathrm{~nm}\right)$. The NMR data (Table 1) further indicated the presence of a $C$-prenyl, a methylenedioxy, and three methoxy groups. The only aromatic proton in the Aring was assigned to $\mathrm{H}-5\left(\delta_{\mathrm{H}} 7.57\right)$ due to its $\mathrm{HMBC}$ correlations (Table 1$)$ to C-4 $\left(\delta_{\mathrm{C}} 175.9\right), \mathrm{C}-6\left(\delta_{\mathrm{C}} 150.9\right), \mathrm{C}-7$ $\left(\delta_{\mathrm{C}} 151.8\right), \mathrm{C}-4 \mathrm{a}\left(\delta_{\mathrm{C}} 120.8\right)$, and C-8a $\left(\delta_{\mathrm{C}} 150.0\right)$. Attachment of the prenyl group to $\mathrm{C}-8$ was indicated by the $\mathrm{HMBC}$ correlations of $\mathrm{CH}_{2}-1^{\prime \prime}\left(\delta_{\mathrm{H}} 3.59\right)$ to $\mathrm{C}-8\left(\delta_{\mathrm{C}} 124.7\right)$ and C-7 $\left(\delta_{\mathrm{C}} 151.8\right)$. One of the methoxy groups $\left(\delta_{\mathrm{H}} 3.95, \delta_{\mathrm{C}} 56.0\right)$ exhibited an NOE to H-5 (7.57), suggesting its placement at C$6\left(\delta_{\mathrm{C}} 150.9\right)$. Another methoxy group $\left(\delta_{\mathrm{H}} 3.92, \delta_{\mathrm{C}} 61.2\right)$ was placed at C-7 based on its HMBC correlation to C-7 $\left(\delta_{\mathrm{C}}\right.$ 151.8). The deshielded ${ }^{13} \mathrm{C}$ NMR chemical shift $\left(\delta_{\mathrm{C}} 61.2\right)$ of the latter methoxy functionality confirms di-ortho alkoxy substitution. ${ }^{22}$ Two para-oriented aromatic proton singlets at $\delta_{\mathrm{H}} 6.63$ and 6.82 were assigned to $\mathrm{H}-3^{\prime}$ and $\mathrm{H}-6^{\prime}$, respectively, with a methoxy group $\left(\delta_{\mathrm{H}} 3.74, \delta_{\mathrm{C}} 56.9\right)$ being positioned at C$2^{\prime}\left(\delta_{\mathrm{C}} 153.0\right)$ and a methylenedioxy functionality at C-4' $\left(\delta_{\mathrm{C}}\right.$ $148.4)$ and ${\mathrm{C}-5^{\prime}}^{\prime}\left(\delta_{\mathrm{C}} 141.2\right)$ of the B-ring based on the HMBC correlations shown in Table 1 and the NOE correlation of $2^{\prime}$ -
Table 1. ${ }^{1} \mathrm{H}(799.87 \mathrm{MHz})$ and ${ }^{13} \mathrm{C}(201.15 \mathrm{MHz}) \mathrm{NMR}$ Spectroscopic Data for 1 Acquired in $\mathrm{CDCl}_{3}$ at $25{ }^{\circ} \mathrm{C}\left[\delta_{\mathrm{C}}\right.$, $\delta_{\mathrm{H}}$, Multiplicity $(J$ in $\left.\mathrm{Hz}), \mathrm{HMBC}\right]$

\begin{tabular}{|c|c|c|c|}
\hline position & $\delta_{\mathrm{C}}$, type & $\delta_{\mathrm{H}}(\mathrm{m}, J$ in $\mathrm{Hz})$ & HMBC \\
\hline 2 & $154.2, \mathrm{CH}$ & $7.97(\mathrm{~s})$ & C-3, C-4, C-1', C-8a \\
\hline 3 & 121.4, C & & \\
\hline 4 & 175.9, C & & \\
\hline $4 a$ & 120.8, C & & \\
\hline 5 & 103.9, CH & $7.57(\mathrm{~s})$ & C-4, C-6, C-7, C-4a, C-8a \\
\hline 6 & $150.9, \mathrm{C}$ & & \\
\hline 7 & 151.8, C & & \\
\hline 8 & 124.7, C & & \\
\hline $8 a$ & 150.0, C & & \\
\hline $1^{\prime}$ & 113.1, C & & \\
\hline $2^{\prime}$ & 153.0, C & & \\
\hline $3^{\prime}$ & 95.5, CH & $6.63(\mathrm{~s})$ & $\mathrm{C}-1^{\prime}, \mathrm{C}-2^{\prime}, \mathrm{C}-4^{\prime}, \mathrm{C}-5^{\prime}$ \\
\hline $4^{\prime}$ & $148.4, \mathrm{C}$ & & \\
\hline $5^{\prime}$ & 141.2, C & & \\
\hline $6^{\prime}$ & $111.2, \mathrm{CH}$ & $6.82(\mathrm{~s})$ & C-3, C-2', C-4', C-5' \\
\hline $1^{\prime \prime}$ & 23.0, $\mathrm{CH}_{2}$ & $3.59(\mathrm{~d}, 7.2)$ & C-7, C-8, C-8a, C-2", C-3" \\
\hline $2^{\prime \prime}$ & 121.6, $\mathrm{CH}$ & $5.22(\mathrm{~m})$ & $\mathrm{C}-4^{\prime \prime}, \mathrm{C}-5^{\prime \prime}$ \\
\hline $3^{\prime \prime}$ & $132.6, \mathrm{C}$ & & \\
\hline $4^{\prime \prime}$ & $17.9, \mathrm{CH}_{3}$ & $1.83(\mathrm{~s})$ & $\mathrm{C}-2^{\prime \prime}, \mathrm{C}-3^{\prime \prime}, \mathrm{C}-5^{\prime \prime}$ \\
\hline $5^{\prime \prime}$ & $25.8, \mathrm{CH}_{3}$ & $1.69(\mathrm{~s})$ & $\mathrm{C}-2^{\prime \prime}, \mathrm{C}-3^{\prime \prime}, \mathrm{C}-4^{\prime \prime}$ \\
\hline $6-\mathrm{OCH}_{3}$ & 56.0, $\mathrm{CH}_{3}$ & $3.95(\mathrm{~s})$ & $\mathrm{C}-6$ \\
\hline 7- $-\mathrm{OCH}_{3}$ & 61.2, $\mathrm{CH}_{3}$ & $3.92(\mathrm{~s})$ & $\mathrm{C}-7$ \\
\hline $2^{\prime}-\mathrm{OCH}_{3}$ & $56.9, \mathrm{CH}_{3}$ & $3.74(\mathrm{~s})$ & $\mathrm{C}-2^{\prime}$ \\
\hline $\mathrm{OCH}_{2} \mathrm{O}$ & 101.4, $\mathrm{CH}_{2}$ & $5.97(\mathrm{~s})$ & $\mathrm{C}-4^{\prime}, \mathrm{C}-5^{\prime}$ \\
\hline
\end{tabular}

$\mathrm{OCH}_{3}\left(\delta_{\mathrm{H}} 3.74\right)$ and $\mathrm{H}-3^{\prime}\left(\delta_{\mathrm{H}} 6.63\right)$. On the basis of the above spectroscopic data, the new compound 1, 8-prenylmilldurone, was characterized as 8-(3,3-dimethylallyl)-6,7,2'-trimethoxy$4^{\prime}, 5^{\prime}$-methylenedioxyisoflavone. It is structurally closely related 
Table 2. ${ }^{1} \mathrm{H}(799.87 \mathrm{MHz})$ and ${ }^{13} \mathrm{C}(201.15 \mathrm{MHz})$ NMR Spectroscopic Data for 2 and 3 Acquired in $\mathrm{CDCl}_{3}$ at $25{ }^{\circ} \mathrm{C}\left[\delta_{\mathrm{C}}, \delta_{\mathrm{H}}\right.$ (Multiplicity, $\mathrm{J}$ in $\mathrm{Hz}$ ), $\mathrm{HMBC}$ ]

\begin{tabular}{|c|c|c|c|c|c|c|}
\hline \multirow[b]{2}{*}{ position } & \multicolumn{3}{|c|}{2} & \multicolumn{3}{|c|}{3} \\
\hline & $\delta_{\mathrm{C}}$ & $\delta_{\mathrm{H}}(\mathrm{m}, J$ in $\mathrm{Hz})$ & HMBC & $\delta_{\mathrm{C}}$ & $\delta_{\mathrm{H}}(\mathrm{m}, J$ in $\mathrm{Hz})$ & $\mathrm{HMBC}$ \\
\hline 1 & $105.8, \mathrm{CH}$ & $6.52(\mathrm{~s})$ & C-2, C-3, C-4a, C-12a & 109.3, $\mathrm{CH}$ & $7.71(\mathrm{~s})$ & C-2, C-3, C-4a, C-12a \\
\hline 2 & $142.3, \mathrm{C}$ & & & $142.4, \mathrm{C}$ & & \\
\hline 3 & 149.3, C & & & 149.5, C & & \\
\hline 4 & 99.1, CH & $6.46(\mathrm{~s})$ & $C-2, C-4 a, C-12 b$ & 98.5, $\mathrm{CH}$ & $6.42(\mathrm{~s})$ & C-2, C-3, C-4a, C-12b \\
\hline $4 a$ & $149.4, \mathrm{C}$ & & & $150.7, \mathrm{C}$ & & \\
\hline 6 & 63.9, $\mathrm{CH}_{2}$ & $4.59(\mathrm{dd}, 2.4,12.0)$ & $C-4 a, C-6 a, C-12 a$ & 61.6, $\mathrm{CH}_{2}$ & $4.37(\mathrm{dd}, 4.0,9.6)$ & C-4a, C-6a, C-12a \\
\hline & & 4.47 (br d, 12.0) & C-6a & & $4.44(\mathrm{dd}, 9.6,11.2)$ & C-6a, C-12a \\
\hline $6 a$ & $75.9, \mathrm{CH}$ & $4.57(t, 2.4)$ & $C-12 a, C-12 b$ & 76.6, $\mathrm{CH}$ & $4.63(\mathrm{dd}, 4.0,11.2)$ & C-6, C-12a \\
\hline $7 \mathrm{a}$ & $162.5, \mathrm{C}$ & & & 161.5, C & & \\
\hline 8 & 100.7, CH & $6.38(\mathrm{~d}, 2.4)$ & C-10, C-7a, C-11a & $100.5, \mathrm{CH}$ & $6.50(\mathrm{~d}, 2.4)$ & C-9, C-10, C-7a, C-11a \\
\hline 9 & 167.1, C & & & 166.1, C & & \\
\hline 10 & 111.1, CH & $6.59(\mathrm{dd}, 2.4,8.8)$ & C-8, C-11a & 111.1, $\mathrm{CH}$ & $6.69(\mathrm{dd}, 2.4,8.8)$ & C-8, C-11a \\
\hline 11 & 129.4, $\mathrm{CH}$ & $7.84(\mathrm{~d}, 8.8)$ & C-9, C-12, C-7a & 130.6, $\mathrm{CH}$ & $7.93(\mathrm{~d}, 8.8)$ & C-9, C-12, C-7a \\
\hline $11 \mathrm{a}$ & 111.0, C & & & 113.6, C & & \\
\hline 12 & 191.2, C & & & 187.0, C & & \\
\hline $12 \mathrm{a}$ & $67.7, \mathrm{C}$ & & & 66.6, C & & \\
\hline $12 b$ & 109.7, C & & & $110.5, \mathrm{C}$ & & \\
\hline 9- $\mathrm{OCH}_{3}$ & $55.7, \mathrm{CH}_{3}$ & $3.79(\mathrm{~s})$ & C-9 & $55.8, \mathrm{CH}_{3}$ & $3.86(\mathrm{~s})$ & C-9 \\
\hline $\mathrm{OCH}_{2} \mathrm{O}$ & 101.3, $\mathrm{CH}_{2}$ & $5.85(\mathrm{~d}, 1.2)$ & C-2, C-3 & 101.5, $\mathrm{CH}_{2}$ & $5.95(\mathrm{~s})$ & C-2, C-3 \\
\hline & & $5.83(\mathrm{~d}, 1.2)$ & & & & \\
\hline $12 \mathrm{a}-\mathrm{OH}$ & & $4.43(s)$ & C-12, C-6a, C-12a & & $2.59(\mathrm{~s})$ & C-6a, C-12b \\
\hline
\end{tabular}

to milldurone (13), an isoflavone that was isolated from the seeds of $M$. dura $^{14}$ and from the leaves of Ateleia glazioviana. ${ }^{15}$

Compound 2 was isolated as a colorless solid (UV $\lambda_{\max } 250$, $269 \mathrm{~nm}$ ) and assigned the molecular formula $\mathrm{C}_{18} \mathrm{H}_{14} \mathrm{O}_{7}$ based on HRESIMS $\left([\mathrm{M}+\mathrm{Na}]^{+} m / z 365.0645\right.$, calcd 365.0637) and NMR analyses (Table 2). The NMR data indicated a 12ahydroxyrotenoid skeleton ${ }^{22-24}$ with a methoxy $\left(\delta_{\mathrm{H}} 3.79, \delta_{\mathrm{C}}\right.$ $55.7)$ and a methylenedioxy $\left(\delta_{\mathrm{H}} 5.83 ; 5.85, \delta_{\mathrm{C}} 101.3\right)$ group as substituents. The presence of a hydroxy group at C-12a was confirmed by the HMBC correlations of the hydroxy proton to C-12 $\left(\delta_{\mathrm{C}} 191.2\right)$, C-6a $\left(\delta_{\mathrm{C}} 75.9\right)$, and C-12a $\left(\delta_{\mathrm{C}} 67.7\right)$. The Dring possesses three mutually coupled aromatic protons, $\mathrm{H}-11$ $\left(\delta_{\mathrm{H}} 7.84\right), \mathrm{H}-10\left(\delta_{\mathrm{H}} 6.59\right)$, and $\mathrm{H}-8\left(\delta_{\mathrm{H}} 6.38\right)$ (Table 2$)$. The HMBC correlations of $\mathrm{H}-11$ with C-9 $\left(\delta_{\mathrm{C}} 167.1\right)$ and C-12 $\left(\delta_{\mathrm{C}}\right.$ 191.2) are consistent with this ring being oxygenated at C-9 $\left(\delta_{\mathrm{C}}\right.$ 167.1), which is corroborated by the HMBC correlation of the methoxy protons $\left(\delta_{\mathrm{H}} 3.79\right)$ to this carbon. The A-ring is 2,3disubstituted, as revealed by the aromatic singlets $\mathrm{H}-1\left(\delta_{\mathrm{H}}\right.$ 6.52) and $\mathrm{H}-4\left(\delta_{\mathrm{H}} 6.46\right)$, placing the methylenedioxy group at $\mathrm{C}-2$ and C-3. Thus, 2 was identified as 12a-hydroxy-9-methoxy2,3-methylenedioxyrotenoid. The equatorial orientation of $\mathrm{H}$ $6 \mathrm{a}\left(\delta_{\mathrm{H}} 4.57\right)$ was established on the basis of the small $J$ values $\left(J_{6 \mathrm{a}, 6}=2.4\right.$ and $\left.<1 \mathrm{~Hz}\right)$ with the C-6 diastereotopic protons $\left(\delta_{\mathrm{H}}\right.$ 4.47 and 4.59). This, along with the chemical shift of $\mathrm{H}-1\left(\delta_{\mathrm{H}}\right.$ $6.51)$, suggests a cis- $\mathrm{B} / \mathrm{C}$ ring junction. ${ }^{25,26}$ The negative specific rotation $\left([\alpha]^{20}{ }_{D}-38.3\right)$ and the negative Cotton effect at $325 \mathrm{~nm}$, in the ECD spectrum (Figure 1), are in agreement with a $(6 \mathrm{a} R, 12 \mathrm{a} R)$ absolute configuration of $2 .^{27}$ The cis-B/C ring fusion and the $(6 \mathrm{a} R, 12 \mathrm{a} R)$ absolute configuration were further corroborated by the computed electronic circular dichroism (ECD) spectra (Figure 1) of the calculated (B3LYP/6-311G) global energy minimum structures (Figure 2). This new compound, oblarotenoid A (2), was therefore characterized as $(6 \mathrm{a} R, 12 \mathrm{a} R)$-12a-hydroxy-9-methoxy-2,3-methylenedioxyrotenoid.

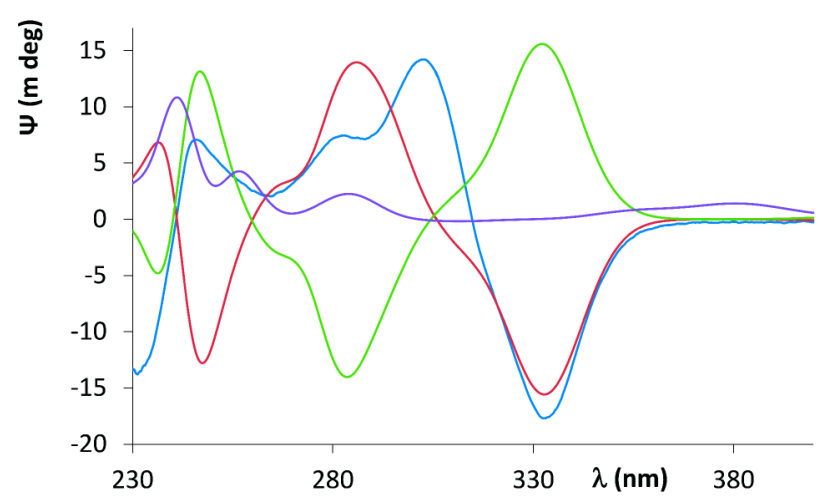

Figure 1. ECD spectra: Experimental 2 (blue), calculated for cis-fused $(6 \mathrm{a} R, 12 \mathrm{a} R)-2$ (red), calculated for cis-fused $(6 \mathrm{aS}, 12 \mathrm{a} S)-2$ (green), and calculated for trans-fused $(6 \mathrm{a} R, 12 \mathrm{a} S)-2$ (violet).

12a-Hydroxymunduserone (6), a rotenoid having an identical oxygenation pattern to 2 , has been reported to be dextrorotatory, $[\alpha]^{20} \mathrm{D}+33.3{ }^{28}$ yet assigned a $(6 \mathrm{a} R, 12 \mathrm{a} R)$ absolute configuration, based on the observation of a negative ECD Cotton effect at $320 \mathrm{~nm}^{29}$ We have isolated the dextrorotatory form, $[\alpha]_{D}^{20}+53.3$, of compound 6 , and it also showed a negative Cotton effect at $330 \mathrm{~nm}$. The ECD spectra of compounds $\mathbf{2}$ and $\mathbf{6}$ are similar and are consistent with that previously proposed ${ }^{27}$ and computationally predicted here for the $(6 \mathrm{a} R, 12 \mathrm{a} R)$ enantiomer. However, these compounds have specific rotations of opposite signs, $[\alpha]^{20}{ }_{D}-38.3(2)$ and $[\alpha]^{20}{ }_{D}+33.3(6){ }^{28}$ indicating that the ECD and the specific rotation data may not always be complementary. The uncertainty associated with the use of the sign of the specific rotation in assigning the absolute configuration of rotenoids is further indicated by the examples of gliricidol and 2methoxygliricidol. These 12a-hydroxyrotenoids are dextrorotatory $^{30}$ and were assigned a $(6 \mathrm{a} R, 12 \mathrm{a} R)$ configuration, although a negative rotation has been associated with almost all 

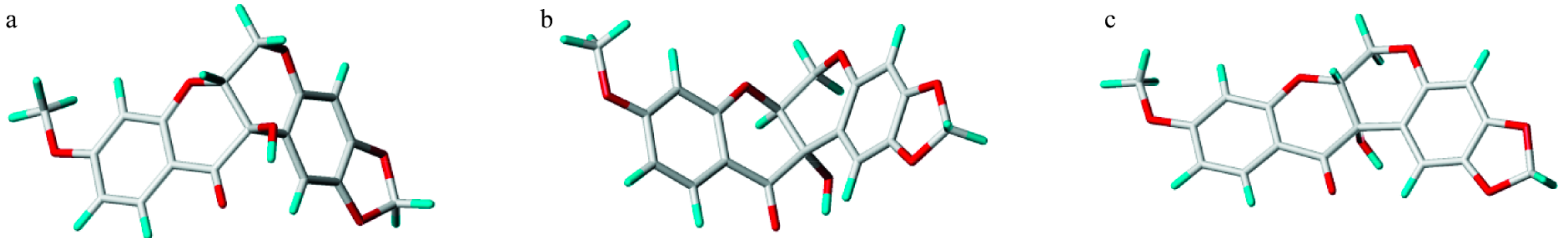

Figure 2. Calculated (B3LYP/6-311G) global energy minimum structures of (a) (6aR,12aR)-2, (b) of $(6 \mathrm{a} S, 12 \mathrm{a} S)-\mathbf{2}$, and $(\mathrm{c})$ of $(6 \mathrm{a} R, 12 \mathrm{a} S)-\mathbf{2}$.

known $(6 \mathrm{a} R, 12 \mathrm{a} R)$-configured 12a-hydroxyrotenoids. ${ }^{27}$ Hence, we propose that the Cotton effect at $300-330 \mathrm{~nm}$ may be a better tool for the assignment of the absolute configuration of 12a-hydroxyrotenoids. The Cotton effect at 330-360 nm, due to an $\mathrm{n} \rightarrow \pi$ transition, has also been proposed to be diagnostic in determining the absolute configuration of rotenoids; however, this band is generally weak ${ }^{26}$ and is often not observed, ${ }^{29}$ limiting its applicability.

Compound 3 was isolated as colorless crystals and showed UV absorption maxima at 285 and $300 \mathrm{~nm}$. HRESIMS analysis did not show a molecular ion but rather a fragment ion at $\mathrm{m} / z$ 325.0702 for $\left[\mathrm{M}+\mathrm{H}-\mathrm{H}_{2} \mathrm{O}\right]^{+}$accounting for the molecular formula, $\mathrm{C}_{18} \mathrm{H}_{14} \mathrm{O}_{6}$. The $\mathrm{H}-6 \alpha\left(\delta_{\mathrm{H}} 4.37\right), \mathrm{H}-6 \beta\left(\delta_{\mathrm{H}} 4.44\right)$, and H-6a $\left(\delta_{\mathrm{H}} 4.63\right)$ as well as C-6 $\left(\delta_{\mathrm{C}} 61.6\right), \mathrm{C}-6 \mathrm{a}\left(\delta_{\mathrm{C}} 76.6\right), \mathrm{C}-12 \mathrm{a}$ $\left(\delta_{\mathrm{C}} 66.6\right)$, and C-12 $\left(\delta_{\mathrm{C}} 187.0\right)$ NMR signals of 3 are consistent with a 12a-hydroxyrotenoid skeleton ${ }^{12,22,23}$ having a methoxy $\left(\delta_{\mathrm{H}} 3.86, \delta_{\mathrm{C}} 55.8\right)$ and a methylenedioxy $\left(\delta_{\mathrm{H}} 5.95, \delta_{\mathrm{C}} 101.5\right)$ group as substituents. Similar to 2 , the ${ }^{1} \mathrm{H}$ NMR spectrum of 3 displayed signals for three mutually coupled aromatic protons at $\delta_{\mathrm{H}} 7.93(\mathrm{~d}, J=8.8 \mathrm{~Hz}, \mathrm{H}-11), 6.69(\mathrm{dd}, J=2.4,8.8 \mathrm{~Hz}, \mathrm{H}-$ $10)$, and $6.50(d, J=2.4 \mathrm{~Hz}, \mathrm{H}-8)$ of the D-ring. The methoxy group was located at C-9 $\left(\delta_{\mathrm{C}} 166.1\right)$ based on its NOE to H-8 $\left(\delta_{\mathrm{H}} 6.50\right)$ and $\mathrm{HMBC}$ correlation with $\mathrm{C}-9$, similar to those observed for 2 . In ring A, two para-oriented aromatic singlets at $\delta_{\mathrm{H}} 7.71$ and 6.42 were assigned to $\mathrm{H}-1$ and $\mathrm{H}-4$, respectively, which, therefore, allowed the placement of the methylenedioxy group at C-2/C-3 $\left(\delta_{\mathrm{C}} 142.4 / 149.5\right)$.

This compound is a stereoisomer of $\mathbf{2}$ having the same core 12a-hydroxy-9-methoxy-2,3-methylenedioxyrotenoid structure. One apparent distinction is that the chemical shift value for $\mathrm{H}-1$ $\left(\delta_{\mathrm{H}} 7.71\right)$ in compound 3 is strongly deshielded compared to that of $\mathbf{2}$ and other rotenoids with a cis-B/C junction. This observation and the large coupling constant between H-6a and one of the C-6 protons $(J=11.2 \mathrm{~Hz}, 1,2$-diaxial $)$ suggested that 3 possesses a trans-orientation at the $\mathrm{B} / \mathrm{C}$-ring junction, which could imply either a $(6 \mathrm{a} R, 12 \mathrm{a} S)$ or a $(6 \mathrm{a} S, 12 \mathrm{a} R)$ absolute configuration. $^{12,22,23}$ The ECD spectrum of 3 (Figure 3) showed a positive Cotton effect at ca. $340 \mathrm{~nm}$ and a negative

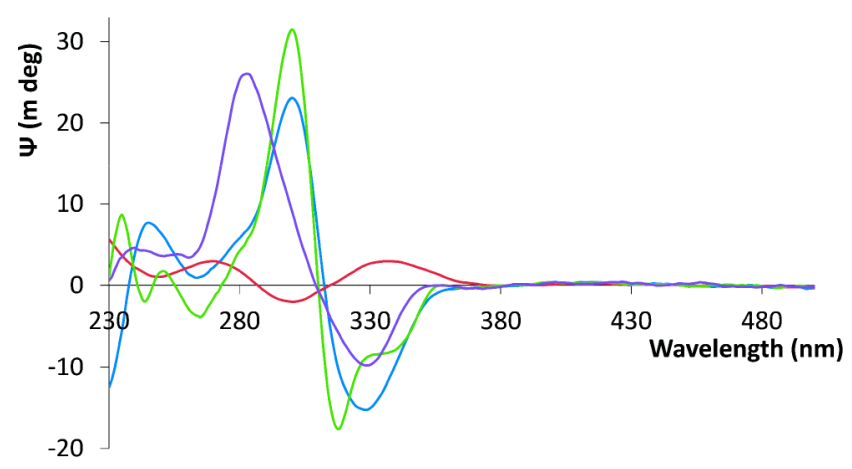

Figure 3. ECD spectra of the rotenoids 2 (blue), 3 (red), 4 (green), and 5 (violet). one at ca. $300 \mathrm{~nm}$, which together with the positive specific rotation, $[\alpha]^{20}{ }_{\mathrm{D}}+130$, reflected a $(6 \mathrm{a} R, 12 S)$ absolute configuration. ${ }^{27}$ This is also similar to the computed ECD spectrum for the $(6 \mathrm{a} R, 12 S)$-configured isomer (Figure 1). Therefore, compound 3 , oblarotenoid $\mathrm{B}$, was characterized as $(6 \mathrm{a} R, 12 \mathrm{a} S)$-12a-hydroxy-9-methoxy-2,3-methylenedioxyrotenoid.

Compound 4 was obtained as needles $\left(\mathrm{CH}_{3} \mathrm{OH}\right)$, with UV absorption maxima at 285 and $300 \mathrm{~nm}$, and assigned the molecular formula $\mathrm{C}_{18} \mathrm{H}_{14} \mathrm{O}_{6}$ based on HRESIMS $\left([\mathrm{M}+\mathrm{H}]^{+}\right.$ $m / z$ 327.0865, calcd 327.0869) and NMR data (Table 3). Its ${ }^{1} \mathrm{H}$ NMR spectrum resembled those of 2 and 3, displaying four mutually coupled aliphatic protons, H- $6 \alpha\left(\delta_{\mathrm{H}} 4.59\right), \mathrm{H}-6 \beta\left(\delta_{\mathrm{H}}\right.$ 4.16), H-6a $\left(\delta_{\mathrm{H}} 4.92\right)$, and $\mathrm{H}-12 \mathrm{a}\left(\delta_{\mathrm{H}} 3.80\right)$, consistent with a rotenoid skeleton. ${ }^{9}$ Whereas the A- and D-rings of 4 have an identical substitution pattern to those of 2 and 3 , its $\mathrm{C}-12$ a is not oxygenated. The chemical shift of $\mathrm{H}-1 \quad\left(\delta_{\mathrm{H}}\right.$ 6.73) is consistent with a cis-B/C ring junction. ${ }^{25-27}$ It should be noted that the 9-methoxy-2,3-methylenedioxyrotenoid core structure of this compound has previously been reported as a synthesized product, $^{31}$ however, without any NMR data to support the structural proposal. The negative and positive ECD Cotton effect (Figure 3) at 340 and $300 \mathrm{~nm}$, respectively, suggested a $(6 \mathrm{a} S, 12 \mathrm{a} S)$ absolute configuration. Although a negative specific rotation has previously been proposed for this configuration, ${ }^{27}$ 4 showed an $[\alpha]^{20}{ }_{D}$ of +38.3 despite its $100 \%$ enantiomeric purity, as established by chiral HPLC analysis. The absolute configuration $(6 \mathrm{a} S, 12 \mathrm{a} S)-4$ was confirmed by single-crystal Xray crystallography (Figure 4). The above analyses suggest that ECD should be preferred above optical rotation for the determination of the absolute configuration of rotenoids. Thus, the structure of compound 4, oblarotenoid $\mathrm{C}$, was defined as $(6 \mathrm{a} S, 12 \mathrm{a} S)$-9-methoxy-2,3-methylenedioxyrotenoid.

Compound 5 was obtained as a colorless solid. It showed UV absorption maxima at 245, 260, and $280 \mathrm{~nm}$ and was assigned the molecular formula $\mathrm{C}_{19} \mathrm{H}_{16} \mathrm{O}_{8}$ based on HRESIMS ([ $\mathrm{M}+$ $\mathrm{H}]^{+} m / z$ 373.0918, calcd 373.0924) and NMR (Table 3) analyses. The three mutually coupled aliphatic protons $\mathrm{H}-6 \alpha$ $\left(\delta_{\mathrm{H}} 4.67\right), \mathrm{H}-6 \beta\left(\delta_{\mathrm{H}} 4.53\right)$, and H-6a $\left(\delta_{\mathrm{H}} 4.59\right)$ were similar to those of 2 and 3 , indicative of a 12a-hydroxyrotenoid skeleton. The broad singlet at $\delta_{\mathrm{H}} 4.40$ was assigned to $\mathrm{OH}-12 \mathrm{a}$, based on its $\mathrm{HMBC}$ correlations to C-12, C-6a, and C-12a. The position of $\mathrm{CH}_{3} \mathrm{O}-9\left(\delta_{\mathrm{H}} 3.80, \delta_{\mathrm{C}} 55.8\right)$, similar to those of 2-4, was determined based on its NOE with $\mathrm{H}-8\left(\delta_{\mathrm{H}} 6.38\right)$, HMBC correlation to C-9 $\left(\delta_{\mathrm{C}} 167.2\right)$, and the coupling pattern of the three mutually coupled aromatic protons $\mathrm{H}-8, \mathrm{H}-10$, and $\mathrm{H}-11$ of the D-ring (Table 3). The A-ring of 5 possesses only one singlet proton, $\mathrm{H}-1\left(\delta_{\mathrm{H}} 6.25\right)$, unusual for a rotenoid, with its position having been determined based on its $\mathrm{HMBC}$ correlation to $\mathrm{C}-12 \mathrm{a} \quad\left(\delta_{\mathrm{C}} 67.4\right)$. The placement of the methylenedioxy group was determined to be at C-3/C-4 based on the HMBC correlation of $\mathrm{H}-1\left(\delta_{\mathrm{H}} 6.25\right)$ to $\mathrm{C}-2\left(\delta_{\mathrm{C}}\right.$ $138.8)$, the carbon that also showed an HMBC cross-peak to the $\mathrm{CH}_{3} \mathrm{O}-2$ protons $\left(\delta_{\mathrm{H}} 3.74\right)$ and had a chemical shift 
Table 3. ${ }^{1} \mathrm{H}(799.87 \mathrm{MHz})$ and ${ }^{13} \mathrm{C}(201.25 \mathrm{MHz}) \mathrm{NMR}$ Spectroscopic Data for 4 and 5 Acquired in $\mathrm{CDCl}_{3}$ at $25{ }^{\circ} \mathrm{C}\left[\delta_{\mathrm{C}}, \delta_{\mathrm{H}}\right.$ (Multiplicity, $\mathrm{J}$ in $\mathrm{Hz}$ ), $\mathrm{HMBC}$ ]

\begin{tabular}{|c|c|c|c|c|c|c|}
\hline \multirow[b]{2}{*}{ position } & \multicolumn{3}{|c|}{4} & \multicolumn{3}{|c|}{5} \\
\hline & $\delta_{\mathrm{C}}$ & $\delta_{\mathrm{H}}(\mathrm{m}, J$ in $\mathrm{Hz})$ & HMBC & $\delta_{\mathrm{C}}$ & $\delta_{\mathrm{H}}(\mathrm{m}, J$ in $\mathrm{Hz})$ & HMBC \\
\hline 1 & 106.9, $\mathrm{CH}$ & $6.73(\mathrm{~s})$ & C-2, C-3, C-4a, C-12a, C-12b & 105.6, $\mathrm{CH}$ & $6.25(\mathrm{~s})$ & C-2, C-3, C-4a, C-12a \\
\hline 2 & 142.3, C & & & $138.8, \mathrm{C}$ & & \\
\hline 3 & $147.8, \mathrm{C}$ & & & 137.9, C & & \\
\hline 4 & $98.8, \mathrm{CH}$ & $6.43(\mathrm{~s})$ & $\mathrm{C}-2, \mathrm{C}-3, \mathrm{C}-4 \mathrm{a}, \mathrm{C}-12 \mathrm{~b}$ & $135.9, \mathrm{C}$ & & \\
\hline $4 a$ & $148.3, \mathrm{C}$ & & & 133.6, C & & \\
\hline 6 & 66.3, $\mathrm{CH}_{2}$ & $4.16($ br d, 12.0) & C-12, C-6a, C-12a & 63.9, $\mathrm{CH}_{2}$ & $4.53(\mathrm{~d}, 12.0)$ & $\mathrm{C}-6 \mathrm{a}$ \\
\hline & & $4.59(\mathrm{dd}, 3.2,12.0)$ & C-12, C-6a, C-12a & & $4.67(\mathrm{dd}, 2.4,12.0)$ & C-4a, C-6a, C-12a \\
\hline $6 a$ & 72.1, $\mathrm{CH}$ & $4.92(t, 3.2,7.2)$ & $C-12, C-6, C-12 b$ & 76.1, $\mathrm{CH}$ & $4.59(\mathrm{dd}, 1.6,2.4)$ & $\mathrm{C}-12 \mathrm{~b}$ \\
\hline $7 a$ & 162.7, C & & & $162.6, \mathrm{C}$ & & \\
\hline 8 & 100.6, $\mathrm{CH}$ & $6.42(\mathrm{~d}, 2.4)$ & C-7a, C-9, C-10, C-11a & $100.8, \mathrm{CH}$ & $6.38(\mathrm{~d}, 2.4)$ & C-10, C-7a, C-11a \\
\hline 9 & $166.5, \mathrm{C}$ & & & $167.2, \mathrm{C}$ & & \\
\hline 10 & 110.7, $\mathrm{CH}$ & $6.57(\mathrm{dd}, 2.4,8.8)$ & C-8, C-11a & 111.3, $\mathrm{CH}$ & $6.61(\mathrm{dd}, 2.4,8.8)$ & C-11a \\
\hline 11 & 129.4, $\mathrm{CH}$ & $7.86(\mathrm{~d}, 8.8)$ & C-9, C-12, C-7a & 129.3, CH & $7.85(\mathrm{~d}, 8.8)$ & C-9, C-12, C-7a \\
\hline $11 \mathrm{a}$ & 112.7, C & & & 111.1, C & & \\
\hline 12 & 189.1, C & & & 190.9, C & & \\
\hline $12 \mathrm{a}$ & $44.9, \mathrm{CH}$ & $3.80(\mathrm{~d}, 7.2)$ & $C-12, C-4 a, C-12 b$ & $67.4, \mathrm{C}$ & & \\
\hline $12 b$ & 105.7, C & & & 113.0, C & & \\
\hline $2-\mathrm{OCH}_{3}$ & & & & $56.9, \mathrm{CH}_{3}$ & $3.74(\mathrm{~s})$ & C-2 \\
\hline 9- $\mathrm{OCH}_{3}$ & 55.7, $\mathrm{CH}_{3}$ & $3.79(\mathrm{~s})$ & C-9 & $55.8, \mathrm{CH}_{3}$ & $3.80(\mathrm{~s})$ & C-9 \\
\hline $\mathrm{OCH}_{2} \mathrm{O}$ & 101.2, $\mathrm{CH}_{2}$ & $5.81(\mathrm{~d}, 1.6)$ & $\mathrm{C}-2, \mathrm{C}-3$ & 102.6, $\mathrm{CH}_{2}$ & $6.02(\mathrm{~d}, 1.3)$ & $\mathrm{C}-3, \mathrm{C}-4$ \\
\hline & & $5.86(\mathrm{~d}, 1.6)$ & & & $5.98(\mathrm{~d}, 1.3)$ & \\
\hline $12 \mathrm{a}-\mathrm{OH}$ & & & & & 4.40 (br s) & C-12, C-6a, C-12a \\
\hline
\end{tabular}

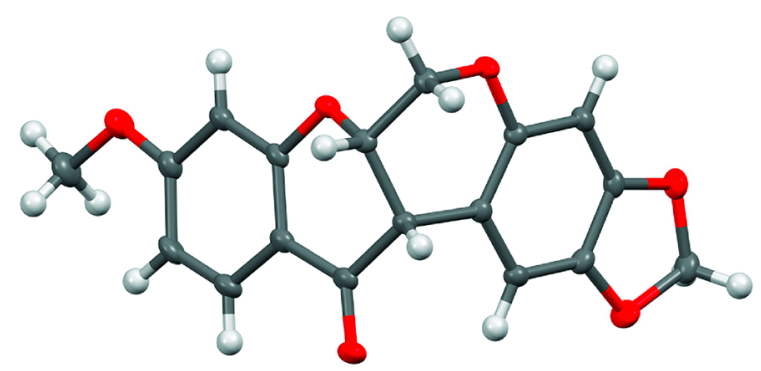

Figure 4. Single-crystal X-ray structure of compound 4.

compatible with the proposed structure. ${ }^{22}$ The chemical shift of $\mathrm{H}-1\left(\delta_{\mathrm{H}} 6.25\right)$ and the small $J_{6,6 \mathrm{a}}(1.6,2.4 \mathrm{~Hz})$ suggested a cis$\mathrm{B} / \mathrm{C}$ ring junction, whereas the absolute configuration was determined as $6 \mathrm{a} R, 12 \mathrm{a} R$ based on the negative Cotton effect at $327 \mathrm{~nm}$ in the ECD spectrum (Figure 3). The structure of compound 5, oblarotenoid $\mathrm{D}$, was therefore characterized as $(6 \mathrm{a} R, 12 \mathrm{a} R)$-12a-hydroxy-2,9-dimethoxy-3,4-methylenedioxyrotenoid and possesses an unprecedented A-ring oxygenation pattern. The co-occurrence of isoflavone 14, with a B-ring oxygenation pattern comparable to that of the A-ring of rotenoid 5, suggests that 5 may be biosynthesized from 14 .

As part of our ongoing investigation of East African medicinal plants in search for novel antitumor natural products, we tested some of the compounds isolated from the leaves of M. oblata ssp. teitensis against the breast cancer cell line MDAMB-231. Maximaisoflavone J (11) and oblarotenoid C (4) showed moderate, $\mathrm{IC}_{50} 33.3 \mu \mathrm{M}$, and low, $\mathrm{IC}_{50} 93.8 \mu \mathrm{M}$, cytotoxicity, respectively. Maximaisoflavone J (11), which has a C- $4^{\prime}$ methoxy substituent, was almost 5 times more active than maximaisoflavone $\mathrm{B}\left(\mathbf{1 0}, \mathrm{IC}_{50} 153.6 \mu \mathrm{M}\right)$, which possesses a methylenedioxy group at C-3'/4'. Compounds $1\left(\mathrm{IC}_{50}>235\right.$ $\mu \mathrm{M})$ and $14\left(\mathrm{IC}_{50} 167.5 \mu \mathrm{M}\right)$ were inactive. The isolated constituents were also tested for in vitro translation inhibition using Krebs-II translation extracts programmed with a bicistronic firefly-HCV IRES-Renilla mRNA construct, to monitor cap-dependent as well as cap-independent translation; ${ }^{32}$ however, none of the compounds showed significant translation inhibitory activity.

In conclusion, one new isoflavone $\mathbf{1}$ and four new rotenoids 2-5 were isolated from the leaves of $M$. oblata ssp. teitensis. Oblarotenoid D (5) has an unusual A-ring oxygenation pattern and is likely biosynthesized from the isoflavone 14 through oxidation of its $\mathrm{OCH}_{3}-2^{\prime}$ and subsequent cyclization. Using Xray crystallography, we have demonstrated the higher reliability of ECD as compared to optical rotation data for determination of the absolute configuration of rotenoids. Among the isolated compounds, maximaisoflavone J (11) and oblarotenoid C (4) showed moderate and low activities, respectively, against the MDA-MB-231 human breast cancer cell line.

\section{EXPERIMENTAL SECTION}

General Experimental Procedures. Melting points were obtained on a Büchi B-545 melting point apparatus. Optical rotations were measured on a PerkinElmer 341-LC, ECD spectra on a Jasco J715 spectropolarimeter, and UV spectra on a Specord S600 (Analytik Jena AG) or a Molecular Devices SpectraMax M2 spectrophotometer. NMR spectra were acquired on a Bruker Avance III HD $800 \mathrm{MHz}$ NMR spectrometer, and the spectra were processed with the MestReNova 10.0 software, using the solvent residual signal as chemical shift reference. LC-MS(ESI) spectra were acquired on a PerkinElmer PE SCIEX API 150EX instrument equipped with a Turbolon spray ion source connected to a Gemini 5 mm RPC $\mathrm{m}_{18} 110 \AA$ column, applying a $\mathrm{H}_{2} \mathrm{O} / \mathrm{MeCN}(80: 20$ to $20: 80$ ) gradient in the presence of $0.2 \% \mathrm{HCOOH}$, with a separation time of $8 \mathrm{~min}$. The HRMS analysis (Q-TOF-MS with a lockmass-ESI source) was done by Stenhagen Analys Lab AB, Gothenburg. TLC analyses were carried out on Merck precoated silica gel $60 \mathrm{~F}_{254}$ plates. Preparative TLC was done on $20 \times 20 \mathrm{~cm}$ glass plates, precoated with silica gel $60 \mathrm{~F}_{254}$ having 0.25 to $1 \mathrm{~mm}$ thickness. Column chromatography was run on silica gel $60 \AA$ (70-230 mesh), whereas gel filtration was performed 
on Sephadex LH-20. Preparative HPLC was carried out on a Waters $600 \mathrm{E}$ instrument using the Chromulan (Pikron Ltd.) software and an $\mathrm{RP} \mathrm{C}_{8}$ Kromasil $(250 \mathrm{~mm} \times 55 \mathrm{~mm})$ column eluting with various $\mathrm{H}_{2} \mathrm{O}-\mathrm{CH}_{3} \mathrm{OH}$ gradients. Enantiomeric purity of oblarotenoid A (2) and oblarotenoid C (4) were determined using chiral HPLC chromatography with a Varian $9012 \mathrm{Q}$ solvent delivery system coupled to a Varian $9050 \mathrm{UV} /$ vis detector, a Chiralpack $\mathrm{AD}$ (amylose tris) column $(250 \mathrm{~mm} \times 4.6 \mathrm{~mm})$, and an $n$-hexane/2-propanol (19:1) eluent mixture with a $1 \mathrm{~mL} / \mathrm{min}$ flow rate. X-ray data were acquired using an Agilent SuperNova Dual diffractometer with Atlas detector at $T=123.0(1) \mathrm{K}$ and mirror-monochromatized $\mathrm{Cu} \mathrm{K} \alpha$ radiation $(\lambda=$ $1.54184 \AA$ ).

Plant Material. The leaves of Millettia oblata ssp. teitensis were collected from Ngangao Forest, Taita Hill, Taita County, Kenya, in July 2014. The plant was identified by Mr. Patrick Chalo Mutiso of the School of Biological Sciences, University of Nairobi, Kenya, where a voucher specimen (TD-04/2014) was deposited.

Extraction and Isolation. The air-dried and ground leaves of M. oblata ssp. teitensis $(1.6 \mathrm{~kg})$ were extracted by percolation with $\mathrm{CH}_{2} \mathrm{Cl}_{2} / \mathrm{CH}_{3} \mathrm{OH}(1: 1), 4 \times 3 \mathrm{~L}$ for $24 \mathrm{~h}$, yielding $120 \mathrm{~g}$ of dark green crude extract following evaporation of the solvents using a rotary evaporator. A $110 \mathrm{~g}$ portion of the crude extract was subjected to column chromatography (silica gel 60, $500 \mathrm{~g}$ ) using $n$-hexane and increasing amounts of EtOAc to give a total of 125 fractions, ca. 250 $\mathrm{mL}$ each. Fractions $31-35$, eluted with $3 \%$ EtOAc in $n$-hexane, were combined and subjected to column chromatography on Sephadex LH20 with $\mathrm{CH}_{2} \mathrm{Cl}_{2} / \mathrm{CH}_{3} \mathrm{OH}$ (1:1) eluent, yielding maximaisoflavone B (10, $4.2 \mathrm{mg}$ ). The separation of fractions $38-44$ by column chromatography over silica gel, eluted with $3 \%$ EtOAc in $n$-hexane, yielded maximaisoflavone $\mathrm{J}(11,8.4 \mathrm{mg})$. Fractions 46-54, eluted with $5 \%$ EtOAc in $n$-hexane, were combined and subjected to column chromatography on Sephadex $\mathrm{LH}-20$ with $\mathrm{CH}_{2} \mathrm{Cl}_{2} / \mathrm{CH}_{3} \mathrm{OH}$ (1:1) eluent to give oblarotenoid $\mathrm{C}(4,33.4 \mathrm{mg}$, needle-like crystals from $\mathrm{CH}_{3} \mathrm{OH}$ ). The mother liquid of the above crystallization was purified on reversed-phase preparative HPLC with a $\mathrm{CH}_{3} \mathrm{OH} / \mathrm{H}_{2} \mathrm{O}$ gradient (60:40 to $90: 10)$ to give oblarotenoid $\mathrm{A}(2,6.3 \mathrm{mg})$ and additional amounts of $4(2.1 \mathrm{mg})$. Fractions 55-62, eluting with 5\% EtOAc in $n$ hexane, were subjected to column chromatography on Sephadex LH20 using $\mathrm{CH}_{2} \mathrm{Cl}_{2} / \mathrm{CH}_{3} \mathrm{OH}$ (1:1) eluent to afford 6a,12a-dehydrodeguelin $(8,53.1 \mathrm{mg})$. Fractions $67-71$, eluted with $7 \%$ EtOAc in $n$ hexane, were combined and separated by column chromatography on Sephadex LH-20 with $\mathrm{CH}_{2} \mathrm{Cl}_{2} / \mathrm{CH}_{3} \mathrm{OH}(1: 1)$ as eluent to give 8prenylmilldurone $(1,17.9 \mathrm{mg})$ as a colorless solid and two major subfractions. The first subfraction was subjected to reversed-phase preparative $\mathrm{HPLC}$ with a $\mathrm{CH}_{3} \mathrm{OH} / \mathrm{H}_{2} \mathrm{O}(60: 40$ to $90: 10)$ gradient to give munduserone $(7,5.4 \mathrm{mg})$ and tephrosin $(9,9.1 \mathrm{mg})$. The second subfraction was separated on reversed-phase preparative HPLC with $\mathrm{CH}_{3} \mathrm{OH} / \mathrm{H}_{2} \mathrm{O}(60: 40$ to $90: 10)$ to afford oblarotenoid B $(3,4.0 \mathrm{mg})$, oblarotenoid A (2, 7.6 mg), and oblarotenoid C (5, 1.4 mg). Fractions 74-77, eluted with $9 \%$ EtOAc in $n$-hexane, were combined and separated on Sephadex LH-20 eluting with $\mathrm{CH}_{2} \mathrm{Cl}_{2} / \mathrm{CH}_{3} \mathrm{OH}$ (1:1) to give 8-prenylmilldurone $(1,3.0 \mathrm{mg})$ and a mixture of two additional compounds. 12a-Hydroxymunduserone $(6,4.3 \mathrm{mg}$, colorless solid) and 7,2',5'-trimethoxy-3',4'-methylenedioxyisoflavone (14, $23.5 \mathrm{mg})$ were separated using column chromatography on silica gel with an $n$ hexane/EtOAc (8:2 to 7:3) gradient. 2',6,7-Trimethoxy-4', $5^{\prime}$-methylenedioxyisoflavone $(13,7.0 \mathrm{mg})$, a colorless, amorphous solid, was isolated from the combined fractions $85-90$, eluting with $10-12 \%$ EtOAc in $n$-hexane, using Sephadex $\mathrm{LH}-20$ and $\mathrm{CH}_{2} \mathrm{Cl}_{2} / \mathrm{CH}_{3} \mathrm{OH}$ (1:1) as eluent. Maximaisoflavone G (12, $98.7 \mathrm{mg})$, a colorless solid, was precipitated from fractions $95-104$, eluted with $20 \%$ EtOAc in $n$ hexane.

8-Prenylmilldurone (1): colorless solid; $\mathrm{mp} 183-185{ }^{\circ} \mathrm{C}$; UV $\left(\mathrm{CH}_{3} \mathrm{OH}\right) \lambda_{\max }(\log \varepsilon) 305(3.88), 280(3.56) \mathrm{nm} .{ }^{1} \mathrm{H}$ and ${ }^{13} \mathrm{C} \mathrm{NMR}$ data, see Table 1 and Figures S2-S8 (Supporting Information); HRESIMS $[\mathrm{M}+\mathrm{H}]^{+} m / z 425.1609$ (calcd for $\mathrm{C}_{24} \mathrm{H}_{25} \mathrm{O}_{7} 425.1601$ ).

Oblarotenoid A (2): colorless solid; $\mathrm{mp} 128-130{ }^{\circ} \mathrm{C}$; $[\alpha]_{\mathrm{D}}^{20}-38.3$; $\mathrm{UV}\left(\mathrm{CH}_{3} \mathrm{OH}\right) \lambda_{\max } 250,269 \mathrm{~nm}$; ECD $\left(\mathrm{CH}_{3} \mathrm{OH}\right): 300$ (23.0833), 327 $(-15.1694) \mathrm{nm} ;{ }^{1} \mathrm{H}$ and ${ }^{13} \mathrm{C}$ NMR data, see Table 2 and Figures S9-
S15 (Supporting Information); HRESIMS $[\mathrm{M}+\mathrm{Na}]^{+} \mathrm{m} / z 365.0645$ (calcd for $\mathrm{C}_{18} \mathrm{H}_{14} \mathrm{O}_{7} \mathrm{Na}$ 365.0637).

Oblarotenoid $B(3)$ : colorless solid; $\mathrm{mp}>205{ }^{\circ} \mathrm{C}$; $[\alpha]^{20}{ }_{\mathrm{D}}+130.3$; $\mathrm{UV}\left(\mathrm{CH}_{3} \mathrm{OH}\right) \lambda_{\max }(\log \varepsilon) 285$ (3.40) and $300(3.45) \mathrm{nm} ; \mathrm{ECD}$ $\left(\mathrm{CH}_{3} \mathrm{OH}\right) 340$ (2.9294), $300(-2.0102) \mathrm{nm} ;{ }^{1} \mathrm{H}$ and ${ }^{13} \mathrm{C}$ NMR data, see Table 2 and Figures S16-S22 (Supporting Information); HRESIMS $\left[\mathrm{M}+\mathrm{H}-\mathrm{H}_{2} \mathrm{O}\right]^{+} \mathrm{m} / z 325.0702$ (calcd for $\mathrm{C}_{18} \mathrm{H}_{13} \mathrm{O}_{6}$ 325.0667).

Oblarotenoid $\mathrm{C}$ (4): needles (from $\mathrm{CH}_{3} \mathrm{OH}$ ); mp $193-195{ }^{\circ} \mathrm{C}$; $[\alpha]^{20}+38.3$; UV $\lambda_{\max }(\log \varepsilon) 285(3.49), 300(3.51) \mathrm{nm} . \mathrm{ECD}$ $\left(\mathrm{CH}_{3} \mathrm{OH}\right) 300$ (31.4803), $340(-7.8223) \mathrm{nm} ;{ }^{1} \mathrm{H}$ and ${ }^{13} \mathrm{C}$ NMR data, see Table 3 and Figures S23-S28 (Supporting Information); HRESIMS $[\mathrm{M}+\mathrm{H}]^{+} m / z 327.0865$ (calcd for $\mathrm{C}_{18} \mathrm{H}_{15} \mathrm{O}_{6} 327.0869$ ).

Oblarotenoid D (5): colorless solid; $\mathrm{mp} 132-134^{\circ} \mathrm{C}$; $[\alpha]^{20}{ }_{\mathrm{D}}-9.04$; UV $\lambda_{\max }(\log \varepsilon) 245$ (3.04), 260 (3.08), 280 (3.01) nm; ECD $\left(\mathrm{CH}_{3} \mathrm{OH}\right) 285$ (25.29), $327(-9.66) \mathrm{nm} ;{ }^{1} \mathrm{H}$ and ${ }^{13} \mathrm{C}$ NMR data, see Table 3 and Figures S29-S37 (Supporting Information); HRESIMS $[\mathrm{M}+\mathrm{H}]^{+} \mathrm{m} / z 373.0918$ (calcd for $\mathrm{C}_{19} \mathrm{H}_{17} \mathrm{O}_{8}$ 373.0924) and $[\mathrm{M}+$ $\mathrm{Na}]^{+} m / z 395.0698$ (calcd for $\mathrm{C}_{19} \mathrm{H}_{16} \mathrm{O}_{8} 395.0742$ ).

Cytotoxicity Assays. Following a published procedure, ${ }^{7,33}$ MDAMB-231 human breast cancer cells were cultured in Dulbecco's modified Eagle's medium (DMEM), supplemented with 10\% (v/v) fetal bovine serum, $2 \mathrm{mM}$ L-glutamine, 100 units $/ \mathrm{mL}$ penicillin, and $100 \mu \mathrm{g} / \mathrm{mL}$ streptomycin at $37^{\circ} \mathrm{C}$ in humidified $5 \% \mathrm{CO}_{2}$. Cells were seeded in 96-well plates at optimal cell density $\left(10^{4}\right.$ cells per well) to ensure exponential growth for the duration of the assay. After a $24 \mathrm{~h}$ preincubation period, the medium was replaced with experimental medium containing the appropriate compound concentrations or vehicle controls $(0.1 \%$ or $1.0 \% \mathrm{v} / \mathrm{v}$ DMSO). Following $72 \mathrm{~h}$ of incubation, cell viability was measured using Alamar Blue (Invitrogen $\mathrm{Ab}$, Lidingö, Sweden) according to the manufacturer's instructions. Absorbance was measured at $570 \mathrm{~nm}$ with $600 \mathrm{~nm}$ as a reference wavelength. Results were expressed as the mean \pm standard error for six replicates as a percentage of vehicle control (taken as 100\%). Experiments were performed independently at least six times. Statistical analyses were performed using a two-tailed Student's $t$ test. $P<0.05$ was considered to be statistically significant.

Translation Inhibitory Assay. A previously developed assay ${ }^{32}$ was used to measure translation inhibitory activity. The compounds were suspended at a concentration of $10 \mathrm{mM}$ in DMSO and subsequently diluted to $200 \mu \mathrm{M}$ in $\mathrm{H}_{2} \mathrm{O}$. They were tested at a final concentration of $20 \mu \mathrm{M}$ in Krebs-2 translation extracts programmed with a bicistronic Firefly-HCV IRES-Renilla luciferase mRNA construct. Translation reactions were incubated at $30{ }^{\circ} \mathrm{C}$ for $60 \mathrm{~min}$, at which point the luciferase activities were measured. Compounds that inhibit only FF would be considered cap-dependent translation inhibitors, compounds that inhibit expression of Ren only would be inhibitors of HCV IRES translation, while compounds that inhibit both FF and Ren would likely be translation elongation inhibitors. None of the compounds were observed to display significant inhibition of translation.

Computation. Conformations were optimized at the B3LYP/6$311 \mathrm{G}^{* *}$ level of theory ${ }^{34,35}$ without any restrictions. The ECD spectra were computed using the time-dependent $\mathrm{DFT}^{36,37}$ algorithm as implemented in the GAUSSIAN 09 software package ${ }^{38}$ using the 6$31 \mathrm{G}^{*}$ basis set. For ECD calculations 15 singlet and 15 triplet states were solved, obtained with the keyword TD $\left(N_{\text {states }}=15,50-50\right)$. All GAUSSIAN results were analyzed and the spectra displayed using the software SpecDis $1.62 .{ }^{39}$ Conformations were weighted according to their Boltzmann distribution. Molecules were displayed using SYBYL$\mathrm{X} 2.1 .1 .^{40}$

\section{ASSOCIATED CONTENT}

\section{S Supporting Information}

The Supporting Information is available free of charge on the ACS Publications website at DOI: 10.1021/acs.jnatprod.7b00255.

NMR, MS, and CD spectra (PDF)

Crystallographic data (CIF) 


\section{AUTHOR INFORMATION}

\section{Corresponding Authors}

*Tel: +254733 832 576. Fax: +254 20444 6138. E-mail: ayenesew@uonbi.ac.ke (A. Yenesew).

*Tel: +4631786 9033. E-mail: mate@chem.gu.se (M. Erdélyi).

ORCID

Kari Rissanen: 0000-0002-7282-8419

Máté Erdélyi: 0000-0003-0359-5970

\section{Notes}

The authors declare no competing financial interest.

\section{ACKNOWLEDGMENTS}

We are grateful to Mr. P. C. Mutiso of the Herbarium, Botany Department, University of Nairobi, for the identification of the plant species for this study. T.D. thanks the German Academic Exchange Service (DAAD) for a Ph.D. scholarship, offered through the Natural Products Research Network for Eastern and Central Africa (NAPRECA). T.D. is also grateful to the Swedish International Development Cooperation Agency (SIDA) for covering the costs of his research visit to Sweden. Financial support from the Swedish Research Council (201605857), the Academy of Finland (K.R.'s grant nos. 263256, 265328, and 292746), the University of Jyväskylä, and the Royal Society of Arts and Sciences in Göteborg is gratefully acknowledged.

\section{REFERENCES}

(1) Banzouzi, J. T.; Prost, A.; Rajemiariaho, M.; Ongoka, P. Int. J. Bot. 2008, 4, 406-420.

(2) Geesink, R. Tephrosiae; The Royal Botanic Gardens: Kew, 1981.

(3) Cheng, J.; Zhao, Y. Y.; Wang, B.; Qiao, L.; Liang, H. Chem. Pharm. Bull. 2005, 53, 419-421.

(4) Yin, T.; Liang, H.; Wang, B.; Zhao, Y. Y. Fitoterapia 2010, 81, 274-275.

(5) Yankep, E.; Njamen, D.; Fotsing, M. T.; Fomum, Z. T.; Mbanya, J. C.; Giner, R. M.; Recio, M. C.; Manez, S.; Rios, J. L. J. Nat. Prod. 2003, 66, 1288-1290.

(6) Wanda, G. J. M. K.; Njamen, D.; Yankep, E.; Fotsing, M. T.; Fomum, Z. T.; Wober, J.; Starcke, S.; Zierau, O.; Vollmer, G. Phytomedicine 2006, 13, 139-145.

(7) Deyou, T.; Gumula, I.; Pang, F.; Gruhonjic, A.; Mumo, M.; Holleran, J.; Duffy, S.; Fitzpatrick, P. A.; Heydenreich, M.; Landberg, G.; Derese, S.; Avery, V.; Rissanen, K.; Erdelyi, M.; Yenesew, A. J. Nat. Prod. 2015, 78, 2932-2939.

(8) Derese, S.; Barasa, L.; Akala, H. M.; Yusuf, A. O.; Kamau, E.; Heydenreich, M.; Yenesew, A. Phytochem. Lett. 2014, 8, 69-72.

(9) Dagne, E.; Yenesew, A.; Waterman, P. G. Phytochemistry 1989, $28,3207-3210$

(10) Ngandeu, F.; Bezabih, M.; Ngamga, D.; Tchinda, A. T.; Ngadjui, B. T.; Abegaz, B. M.; Dufat, H.; Tillequin, F. Phytochemistry 2008, 69, $258-263$.

(11) Yenesew, A.; Kiplagat, J. T.; Derese, S.; Midiwo, J. O.; Kabaru, J. M.; Heydenreich, M.; Peter, M. G. Phytochemistry 2006, 67, 988-991.

(12) Dagne, E.; Mammo, W.; Bekele, A. Bull. Chem. Soc. Ethiopia 1991, 5, 81-86.

(13) Yenesew, A.; Midiwo, J. O.; Waterman, P. G. Phytochemistry 1997, 47, 295-300.

(14) Ollis, W. D.; Rhodes, C. A.; Sutherland, I. O. Tetrahedron 1967, 23, 4741-4760.

(15) Yokosuka, A.; Haraguchi, M.; Usui, T.; Kazami, S.; Osada, H.; Yamori, T.; Mimaki, Y. Bioorg. Med. Chem. Lett. 2007, 17, 3091-3094.

(16) Na, Z.; Song, Q. S.; Hu, H. B. Rec. Nat. Prod. 2013, 7, 307-312.
(17) Ortega, A. R.; Toscano, R. A.; Hernández-Barragán, A.; AlvarezCisneros, C.; Joseph-Nathan, P. Magn. Reson. Chem. 2015, 53, 860865.

(18) Ye, H.; Fu, A.; Wu, W.; Li, Y.; Wang, G.; Tang, M.; Li, S.; He, S.; Zhong, S.; Lai, H.; Yang, J.; Xiang, M.; Peng, A.; Chen, L. Fitoterapia 2012, 83, 1402-1408.

(19) Tewtrakul, S.; Cheenpracha, S.; Karalai, C. Phytomedicine 2009, $16,568-572$.

(20) You-zhi, L.; Han-hong, X. Sci. Agaric. Sin. 2007, 40, 1688-1696.

(21) Van Puyvelde, L.; De Kimpe, N.; Mudaheranwa, J.-P.; Gasiga, A.; Schamp, N.; Declercq, J.-P.; Van Meerssche, M. J. Nat. Prod. 1987, 50, 349-356

(22) Panichpol, K.; Waterman, P. G. Phytochemistry 1978, 17, $1363-$ 1367.

(23) Messana, I.; Ferrari, F.; Santana, A. E. G. Phytochemistry 1986, $25,2688-2689$.

(24) Yenesew, A.; Derese, S.; Midiwo, J. O.; Oketch-Rabah, H. A.; Lisgarten, J.; Palmer, R.; Heydenreih, M.; Peter, M. G.; Akala, H.; Wangui, J.; Liyala, P.; Waters, N. C. Phytochemistry 2003, 64, 773-779.

(25) Kostova, I.; Ognyanov, I. Monatsh. Chem. 1986, 117, 689-693.

(26) Vasconcelos, J. N. E.; Santiago, G. M. P.; Lima, J. Q.; Mafezoli, J.; de Lemos, T. L. G.; da Silva, F. R. L.; Lima, M. A. S.; Pimenta, A. T. A.; Braz-Filho, R.; Arriaga, A. M. C.; Cesarin-Sobrinho, D. Quim. Nova 2012, 35, 1097-1100.

(27) Slade, D.; Ferreira, D.; Marais, J. P. J. Phytochemistry 2005, 66, 2177-2215.

(28) Kalra, A. J.; Krishnamurti, M.; Nath, M. Indian J. Chem. B 1977, $15,1084-1086$

(29) Wu, X.; Liao, H. B.; Wu, K.; Cui, L. Open Access Lib. J. 2016, 3, e2740.

(30) Rastrelli, L.; Berger, I. I.; Kubelka, W.; Caceres, A.; De Tommasi, N.; De Simone, F. J. Nat. Prod. 1999, 62, 188-190.

(31) Miyano, M. J. Org. Chem. 1970, 35, 246-249.

(32) Novac, O.; Guenier, A. S.; Pelletier, J. Nucl. Acid Res. 2004, 32, 902-915.

(33) Abdissa, N.; Pan, F.; Gruhonjic, A.; Grafenstein, J.; Fitzpatrick, P. A.; Landberg, G.; Rissanen, K.; Yenesew, A.; Erdelyi, M. J. Nat. Prod. 2016, 79, 2181-2187.

(34) Becke, A. D. J. Chem. Phys. 1993, 98, 1372-1377.

(35) Lee, C. T.; Yang, W. T.; Parr, R. G. Phys. Rev. B: Condens. Matter Mater. Phys. 1988, 37, 785-789.

(36) Bauernschmitt, R.; Ahlrichs, R. Chem. Phys. Lett. 1996, 256, 454-464.

(37) Autschbach, J.; Ziegler, T.; van Gisbergen, S. J. A.; Baerends, E. J. J. Chem. Phys. 2002, 116, 6930-6940.

(38) Frisch, M. J.; Trucks, G. W.; Schlegel, H. B.; Scuseria, G. E.; Robb, M. A.; Cheeseman, J. R.; Scalmani, G.; Barone, V.; Mennucci, B.; Petersson, G. A.; Nakatsuji, H.; Caricato, M.; Li, X.; Hratchian, H. P.; Izmaylov, A. F.; Bloino, J.; Zheng, G.; Sonnenberg, J. L.; Hada, M.; Ehara, M.; Toyota, K.; Fukuda, R.; Hasegawa, J.; Ishida, M.; Nakajima, T.; Honda, Y.; Kitao, O.; Nakai, H.; Vreven, T.; Montgomery, J. A.; Peralta, J. E.; Ogliaro, F.; Bearpark, M.; Heyd, J. J.; Brothers, E.; Kudin, K. N.; Staroverov, V. N.; Kobayashi, R.; Normand, J.; Raghavachari, K.; Rendell, A.; Burant, J. C.; Iyengar, S. S.; Tomasi, J.; Cossi, M.; Rega, N.; Millam, N. J.; Klene, M.; Knox, J. E.; Cross, J. B.; Bakken, V.; Adamo, C.; Jaramillo, J.; Gomperts, R.; Stratmann, R. E.; Yazyev, O.; Austin, A. J.; Cammi, R.; Pomelli, C.; Ochterski, J. W.; Martin, R. L.; Morokuma, K.; Zakrzewski, V. G.; Voth, G. A.; Salvador, P.; Dannenberg, J. J.; Dapprich, S.; Daniels, A. D.; Farkas, Ö.; Foresman, J. B.; Ortiz, J. V.; Cioslowski, J.; Fox, D. J. Gaussian 09, Revision A.02; Gaussian, Inc.: Wallingford, CT, 2009.

(39) Bruhn, T.; Schaumlöffel, A.; Hemberger, Y.; Bringmann, G. SpecDis, Version 1.62 ed.; University of Wuerzburg: Germany, 2014.

(40) SYBYL-X 2.1.1; Tripos a Certara Company: St., Louis, MO, USA, 2013. 